\title{
Karaçi Koleji Öğretmenleri Arasında İşe Bağlı Kas-İskelet Sistemi Bozukluklarının Sıklığı \\ $\underline{\text { Shahab-UDDIN }}^{1}, \underline{\text { Muhammad ASIF }}^{2}, \underline{\text { Hira Islam RAJPUT }}{ }^{2}, \underline{\text { Muhammad Riaz Baig CHUGHTAI }}^{1}, \underline{\text { Muhammad Atif KHAN }}{ }^{2}, \underline{\text { Hina }^{2}}$ ${\underline{\mathrm{BADAR}^{3}}}^{3}, \underline{\text { Saher PASHA }}{ }^{2}$
}

\begin{abstract}
$\ddot{\mathbf{O} z}$
Araştırmada Karaçi kolej öğretmenleri arasında işle ilgili kas-iskelet sistemi bozukluklarının prevalansının belirlenmesi amaçlandı. $\mathrm{Bu}$ çalışma kesitsel bir çalışmadır. Karaçi kolejlerinden öğretmenler rastgele seçilmiştir. Veriler Ocak 2018 ile Haziran 2018 arasında toplanmıştır. Her iki cinsiyetten kolej öğretmenlerini uygun örneklemeyle seçtik. Araştırmaya katılan öğretmenler öğretimde yaklaşık bir yıllık iş tecrübesine sahipti. İşe bağlı kas-iskelet sistemi rahatsızlıklarını belirlemek için İskandinav Anketi kullanılmıştır. Anketler 400 ara sınıf öğretmenine gönderilmiş ve toplam 342 öğretmen anket formunu doldurmuş ve geri göndermiştir. İstatistiksel analiz, SPSS 21 sürümü ile yapıldı. Öğretmenler işe başladığı zaman işe bağlı ağrının en yüksek prevalansı boyun, omuz, bel ve dizlerde olduğu bulunmuştur. Katılımcıların\% 50'si boyunlarını bükülme pozisyonunda tuttuklarına ve kara tahta kullanırken omuzlarının yüksek olduğuna cevap verdi. Bu çalışmanın sonucu, öğretmenlerin en çok boyun, omuz, bel ve diz bölgelerinin etkilendiği sonucuna varıldı. Ergonomik kuralların kullanılması sorunu hafifletmeye yardımcı olabilir.
\end{abstract}

Anahtar Kelimeler: Prevalans, işe bağlı kas iskelet sistemi hastalıkları, öğretmenler, postural eğitim
Yayın Bilgisi

Gönderi Tarihi:20.10.2018

Kabul Tarihi:08.03.2019

Online Yayın Tarihi: 30.09.2019

DOI: $10.26453 /$ otjhs. 472850

Sorumlu Yazar

Hira Islam RAJPUT

Isra Institute of Rehabilitation

Sciences

Isra University, Karachi Campus ST-7/A, Block-5, Gulshan-e-Iqbal,

Karachi, Sindh, Pakistan.

Tel: $0092-334-3217735$

e-Mail: hirarajputh@hotmail.com

\section{Prevalence of Work Related Musculoskeletal Disorders among College Teachers of Karachi}

$\underline{\text { Shahab-UDDIN }}^{1}$, Muhammad ASIF $^{2}$, $\underline{\text { Hira Islam RAJPUT }}^{2}, \underline{\text { Muhammad Riaz Baig CHUGHTAI }}^{1}$, $\underline{\text { Muhammad Atif KHAN }}^{2}$, $\underline{\text { Hina }}^{2}$ ${\underline{\mathrm{BADAR}^{3}}}^{3}, \underline{\text { Saher PASHA }}^{2}$

\begin{abstract}
It was aimed to be determined the prevalence of work-related musculoskeletal disorders among college teachers of Karachi in the study. The study was a cross-sectional study. Teachers were randomly selected from different colleges of Karachi. The data collected from January 2018 to June 2018. We selected college teachers from both gender by convenient sampling. Those selected, were subjected had a work experience of about one year in teaching. Nordic questionnaire was used to determine the work related musculoskeletal disorders. The questionnaires were sent to 400 intermediate teachers and 342 completely filled questionnaires were returned back. Statical analysis was done through SPSS version 21 . The highest prevalence of work related pain was found neck, shoulder, lower back, and knees and pain starts when teachers perform their work. 50\% participants responded that they keep their neck in bending position and shoulders elevated while using black board. The result of this study was concluded that neck, shoulder, lower back, and knees are mostly affected regions among teachers. The use of ergonomically rules can help to alleviate the problem.
\end{abstract}

Keywords: Prevalence, work related musculoskeletal disorders, teachers, postural training

\footnotetext{
${ }^{1}$ Jinnah Postgraduate Medical Centre, Karachi, Pakistan.

${ }^{2}$ Isra Institute of Rehabilitation Sciences, Isra University, Karachi Campus, Pakistan.

${ }^{3}$ Physio Clinics, Karachi, Pakistan.
}

Article Info

Received: 20.10 .2018

Accepted: 08.03.2019

Online Published: 30.09.2019

DOI: $10.26453 /$ otjhs. 472850

Corresponding Author Hira Islam RAJPUT

Isra Institute of Rehabilitation Sciences

Isra University, Karachi Campus ST-7/A, Block-5, Gulshan-e-Iqbal,

Karachi, Sindh, Pakistan.

Tel: 0092-334-3217735 e-Mail: hirarajputh@hotmail.com

\section{INTRODUCTION}

Range of degenerative
tendons, lisorders effecting
accompanying nerves and vessels, resulting in pain and discomfort are termed as Musculoskeletal disorders. When these musculoskeletal disorders results as a job related happening they are termed as Workrelated musculoskeletal disorders (WMSDs). MSD's are amongst the major reasons of motion restrictions and enduring disability. ${ }^{1}$ According to WHO musculoskeletal disorders are major cause or reason of absenteeism from the job or work. Also a considerable amount of money is 
spent because of these disorders. These disorders may involve different body regions. The severity of their symptoms varies from ache to severe pain. ${ }^{2}$ WHO defined WMSDs as follows WMSD results from a number of causes and issues. In these issues, the environment of work and performance both contribute, but the amount of influence on the cause may vary. ${ }^{3}$

WMSDs are the conditions that involve musculoskeletal structures like tendons, muscles, ligaments etc. and the cause of these conditions are not of acute nature. They develop when the physical demands of the working place or occupation causes damage to any \& body part. WMSD may be develops by frequent acquiring of bad postures or forceful or again and again repeating the movements which exert pressure or demand more energy. The risk of developing WMSD increases with frequent exposure to such conditions. ${ }^{4}$

According to Occupational Health \& Safety Centre of Canada, WMSDs are disorders that are painful and they involve muscles, nerve \& tendons. The causes may include frequency of repetition, acquiring bad postures. These disorders are painful at rest as well as at work place. As upper limb is involved in almost all the works so upper extremity is mostly involved in WMSDs, whereas lower extremity \& back can also be involved where they are utilized during the work. WMSDs do not develop due to a single trauma. They result from repetitive episodes of trauma. They gradually \& slowly come into existence. ${ }^{5}$ WMSDs are among the leading reasons of work related disabilities and being absent from work. ${ }^{6}$ According to a paper by Hogg-Johnson $50 \%$ to $80 \%$ of the population in developed countries have had back pain during their whole life span. Also $30 \%$ of all the lost time claims are due to back disorders. ${ }^{7}$

WMSDs are very common among many occupations as well as teachers. Its incidence is quite high among the school teachers. A study shows that teachers are prove to develop the WMSDs because of the awkward postures they acquire during their job. ${ }^{8}$ Other study says that teachers in physical education are more prone to acute or chronic injuries due to their work and this leads to retirement before time and age. ${ }^{9}$ There are some ergonomically issues also associated with the causation of WMSD among the teachers. In China a study showed that WMSD prevalence is very high among teachers. It may develop in neck, shoulder, low back, wrist/hand, elbow \& knees. ${ }^{10}$

If we talk about the causing factors of WMSDs among the teachers the causes may include age, gender and BMI. Also working under pressure situations may also contribute in causing WMSDs. $^{11}$ If we talk about teachers dealing nurseries the cause may be lifting kids \& carry them. ${ }^{12}$ The studies also show that the cause of premature retirement among teachers is WMSDs. ${ }^{3}$ Beside this studies show that back was the region mostly affected by WMSDs among the teachers of Malaysia and China. ${ }^{7}$ The 
study also shows that the older i.e. experienced teachers are more prone to develop WMSDs. Also female teachers show high prevalence of WMSDs than male teachers. ${ }^{8}$ The study also shows that psychosocial issues can also contribute in the causation of WMSDs among the teachers. ${ }^{13}$ Ergonomically issues like furniture selection for classes and laboratories can also play important role. ${ }^{14}$

WMSDs can be prevented if good ergonomically procedures are employed. It includes maintain the work surface according to height, adjusting the chair and use of appropriate furniture. ${ }^{15}$ The objective of this study was to determine the prevalence of work related musculoskeletal disorders among the college teachers. By knowing this, helpful strategies would become easy to make as when we know the issue we can solve it better. They can make strategies to cope up with these problems and in turn this will help to enhance their skills. (No disorder no absenteeism).

\section{MATERIAL AND METHODS}

It was a cross sectional study that was conducted in Isra Institute of Rehabilitation Sciences Karachi Campus. This study was approved from the institutional ethical review committee of Isra University vide number IERC/IIRS-IU-KC/17/023. The duration of the study was six months from January 2018 to June 2018. 342 participants were selected by convenient sampling from different public and private intermediate colleges of Karachi and sample size was calculated by Roasoft sample size calculator. The targeted population of this study was both gender and had a work experience of about one year as intermediate college teacher were included in this study. Lab assistants and administrative staff were excluded from this study. Those participants who had a history of severe trauma such as a fracture and history of any accidents were also excluded from the study. After the signing of consent form, the valid Nordic Musculoskeletal questionnaire was distributed to all the participants. First section of the questionnaire contained questions related to age, gender, weight, height, BMI working hours and sleeping hours. Second section contained questions regarding WMSDs in different regions of body from 12 months and from last 7 days. Gathered data was coded and analyzed by software Statistical Package for Social Sciences (version 20.0). Prevalence, Frequency and percentages were calculated.

\section{RESULT}

342 teachers were selected from different intermediate colleges of Karachi with a mean value of age (mean33), and having a standard deviation of (S.D \pm 11.57). Ratio of female respondents was greater $(61.4 \%)$ as compared to males $(38.6 \%)$. Those participants who were working from 1-5 years were $17.5 \%$ participants, 26.3\% participants were working from 6-10 
years, $14 \%$ from 11-15years whereas $42.1 \%$ participants were working from more than 15 years. $52.6 \%$ participants were lying in the BMI category of overweight. (Table 1) Prevalence rate of musculoskeletal disorders among college teachers was $57 \%$. The figure 1 shows the detail of pain in different body region since 12 months, most of the participants had pain in neck (57.9\% participants say yes), Rt. Shoulder (43.9\% participants say yes), lower back (29.8\% participants say yes) and knees (22.8\% participants say yes). The results of musculoskeletal pain in different body regions since last 7 days were shown in figure 2, the most of the participants complaint of pain in neck (47.4\% participants say yes), rt. Shoulder (36.8\% participants say yes), lower back (29.8\% participants say yes), upper back (28.1\% participants say yes) \& knees $(22.8 \%$ participants say yes).

\section{DISCUSSION}

All the musculoskeletal disorders that develop due to any sort of problem related to work or job that the affected person is doing is called Work Related Musculoskeletal Disorders or WMSD. Here we discussed about teachers. Teachers may be teaching students at different levels and each level has their own responsibility and liabilities. Teachers teaching at intermediate level the teachers not only have to teach their respective subjects but they also have to prepare different notes for their subject also at this level the students have many issues so the teachers also have to work to do counseling of these students to solve the issues. Beside this when it comes to teaching and dedicated teaching, the teachers have to search for best known knowledge to convey to their students. For this purpose they may have to read a lot or sit on computer for long periods to search for accurate and appropriate information. If we look at the working procedures that the teachers may employ to convey the knowledge to their students they may have to stand or sit for long hours. When we study on the prolong sitting or standing it is known that prolong acquiring of a certain posture may lead to increased pressure on intervertebral discs and when this pressure is increased, this increased pressure may lead to disorders associated with intervertebral discs i.e. it may cause neck or back pain. $^{15}$

This study showed that the activity level of teachers may be low due to which they gain weight and their BMI increases as their weight increases. Also we can associate this with the prolong durations of work that the teachers have to do. This shows that the activity level of teachers may be low because of their prolong work durations.

If we look at the musculoskeletal disorders among teachers of intermediate level we found that neck pain has high prevalence i.e. $57.9 \%$. This can be associated with a previous study done in China which showed prevalence for 
neck pain as $48.7 \%$ among teachers. ${ }^{9}$ The reason for this high prevalence may be head down posture for prolong durations. ${ }^{7}$ This may be associated with neck pain or it may also be due to prolong use. This prevalence may be associated with previous study by Lawrence I. This study's results showed 55\% problem in shoulders, this study was done on nurses. ${ }^{11}$

The responses to neck pain since last 7 days were found to be $47.4 \%$ \& that for shoulder was found to be $36.8 \%$. Again the cause may be repetitive movements or awkward postures. The results show that $42.1 \%$ \& $29.8 \%$ of teachers reported pain at lower back \& upper back respectively. These can be associated with previous study done by Beyen et al in Ethiopia. ${ }^{3}$ This study showed L.B.P. in $57.5 \%$ of participants. If we look at the pain since last 7 days we found that $29.8 \%$ \& $28.1 \%$ of participants showed pain in lower back and upper back respectively. If we discuss the reason of this pain, the reason may be awkward posture. As discussed earlier, teachers have to sit or stand for prolong duration, this may cause discomfort and if despite of discomfort the same posture remains the condition may get worst. ${ }^{3}$

The results of this current study showed that $22.8 \%$ of participants had knee problems. This can be associated with the results of previous study done in China in 2012. This study showed that $22.6 \%$ of the participating teachers had knee pain. ${ }^{9}$
The results showed that the college teachers had high prevalence of musculoskeletal disorders. These disorders also had prevented many of the participants to perform their daily routine work. These postures and movements may limit the activities of the suffering person. ${ }^{16}$ As we have seen that WMSDs was found to be for neck and shoulder among the intermediate teachers so this prevention from activity may be associated with their high prevalence. Beside this we can say that if the persisting problem remains for long period it may lead to prevent the sufferer from performing his or her daily activities.

The study done in 2009 by Rahman S et al had showed that obesity was associated with low back pain. ${ }^{17}$ In this current study, mostly participants had pain in different region and had high BMI. The study done in 2006 by Adamson J. et al. had shown that high BMI is associated with hip, knees, ankle \& feet pain. So we can say that those participants who complaint of pain of knee, ankle or hip may be because of their high BMI. ${ }^{18}$ High BMI itself are dangerous for health. Obesity is said to be a cause of many diseases so if a person is having high BMI that person may develop many diseases. If we talk about the musculoskeletal disorders they can also develop if a person has high BMI. High BMI means that a person is over weighted or obese and if a person has high BMI over all mass of that person would be increased. More effort means more energy consumption and more muscle work. If the musculature or 
skeletal system of this person having high BMI, is weak or incapable to perform the work this can lead to injury and resulting into musculoskeletal disorders.

Ergonomics is a field which makes the environment individual friendly. If the correct use of ergonomics is employed in the working environments the injuries can be minimized. Also if the valuable rules of ergonomics are applied in the working environment of the teachers this can minimize the injuries and disorders caused by work related issues.

\section{CONCLUSION}

This study was conducted to evaluate the prevalence of WMSDs among intermediate teachers. The prevalence of WMSDs among intermediate teachers was $57 \%$. The results further concluded that neck, shoulder, lower back, and knees are mostly painful regions among college Teachers. The use of ergonomically rules can help to alleviate the problem. This study has proved that there is high prevalence of WMSDs among intermediate teachers, looking at this I may recommend that awareness programs related to posture awareness and ergonomics should be conducted. Also it should be made essential that good ergonomically designed furnishers may be used to minimize this high prevalence.

\section{ACKNOWLEDGEMENT}

I want to acknowledge Dr. Muhammad Asif (Supervisor) and Dr. Hira Islam Rajput for their support and help. Also I would like to acknowledge the examination committee. I would like to thank all my teachers and friends for being there always to help me whenever I needed them. Also want to thank my fellow students and colleagues. In the end I would like to thank my wife, Dr. Hina Shah for her co-operation, tolerance and patience.

\section{REFERENCES}

1. Simoneau S, ST-Vincent S, Chicoine D. Work-Related Musculoskeletal Disorder. A better understanding for more effective prevention published by IRSST \& A.S.P Metal-Electrique. Available at http://www.irsst.qc.ca/media/documents/PubI RSST/RG.126-ang.pdf. Accessed January 11, 2017.

2. Luttmann PA, Jager PM, Griefahn PB. Protecting Worker's Health Series \#5. Preventing Musculoskeletal disorders in workplace.

http://www.who.int/occupationalhealth/publi cations/muscdisorder/en. Accessed January $28,2017$.

3. Beyen TK., Mengestu MY, Zele YT. Low Back Pain \& Associated Factors among Teachers in Gondar Town, North Gondar, 
Amhara Region Ethiopia Occup. Med Health Affairs. 2013;1(5):22-25.

4. Silverstein B, Adams D, Kalat J. Workrelated Musculoskeletal Disorders of the Neck, Back and Upper Extremity in Washington State, 1994-2002. Technical Report 40-8a-2004.

5. Canadian Centre for Occupational Health \& Safety

www.ccohs.ca/oshanswers/diseases/rmirsi.ht ml. Accessed October 25, 2017.

6. Abaraogu UO, Olawale OA, Odebiyi DO, et al. Self-Reported Work Organization indices are associated with prevalence of work related musculoskeletal disorders among Bottling Workers. Continental Journal Applied Science. 2012;7(2);28-34.

7. Darwish Ma, Al-Zuhair. Musculoskeletal Pain Disorders among Secondary School Saudi Female Teachers. Pain Research and Treatment. 2013;5:7-14.

8. Samad NIA, Abdullah H, Moin S, et al. Prevalence of low back pain and its risk factors among school teacher. American Journal of Applied Sciences. 2010;7(5):634639.

9. Li L, Yue, Liu F. Work-related musculoskeletal disorders among school teachers in China, prevalence and occupational factors. In j Prev. 2012;18:162.

10. Yue P, Liu F, Li L. Neck/Shoulder pain and low back pain among school teachers in
China, prevalence and risk factors. BMC Public Health. 2012;12:789.

11. Lawrence I. Musculoskeletal Disorders in Nigeria Nursery Schools: Work related Risk Reduced. Journal of Advances in life Sciences \& Technology. 2012;5:25-28.

12. Tsuboi H, Takeuchi K, Watanabe $\mathrm{M}$, et al. Psychosocial Factors Related to Low Back Pain among School Personnel in Nagoya, Japan. Journal of Industrial Health. 2002;40:266-271.

13. Hashim A, Dawal SZ. Evaluation of Students on Working Postures in School Workshop. International Journal of Ergonomics (IJEG). 2013; 3(1): 86.

14. Ronald S. Environmental Health and Safety. http://www.usi.edu/riskmgt/ergonpreventdiso rders.asp. Accessed January 9, 2018.

15. Hall SJ. Basic Biomechanics. 5th ed. Mc Graw Hill; 2007. http.www.ccohs.ca/oshanswers/diseases/rmir si.html. Accessed January 9, 2018.

16. Korkmaz NC, Cavlak U, Telci EA, et al. Musculoskeletal pain, associated risk factors and coping strategies in school teachers. Scientific Research \& Essay. 2011;6:649657.

17. Rahman S, Karppinent, Arjas PL, et al. The Association b/w obesity \& low back pain. American Journal of Epidemiology. 2009;171(2):135-154.

18. Adamson J. Ebrahim S, Dieppn P, et al. Prevalence and Risk factor for joint pain 
among men and women in the west of 2006;69:520-524.

Scotland Twenty-07 study. Ann Rheum Dis. 
Table 1. Demographic Details $(\mathrm{N}=342)$

\begin{tabular}{llcc}
\hline Variables & & Frequency & Percent \\
\hline Age & 25-34years & 114 & 33.3 \\
& 35-44years & 78 & 22.8 \\
& $45-54$ years & 96 & 28.1 \\
& 55 \& above & 54 & 15.8 \\
\hline Gender & Male & 132 & 38.6 \\
& Female & 210 & 61.4 \\
\hline Years of experience & $1-5$ years & 60 & 17.5 \\
& 6-10 years & 90 & 26.3 \\
& $11-15$ years & 48 & 14.0 \\
& more than 15 years & 144 & 42.1 \\
\hline Daily work hours & $1-5$ hours & 30 & 8.8 \\
& 6-10 hours & 312 & 91.2 \\
\hline BMI & b/w18 and 23 & 162 & 47.4 \\
& above 23 & 180 & 52.6 \\
\hline
\end{tabular}




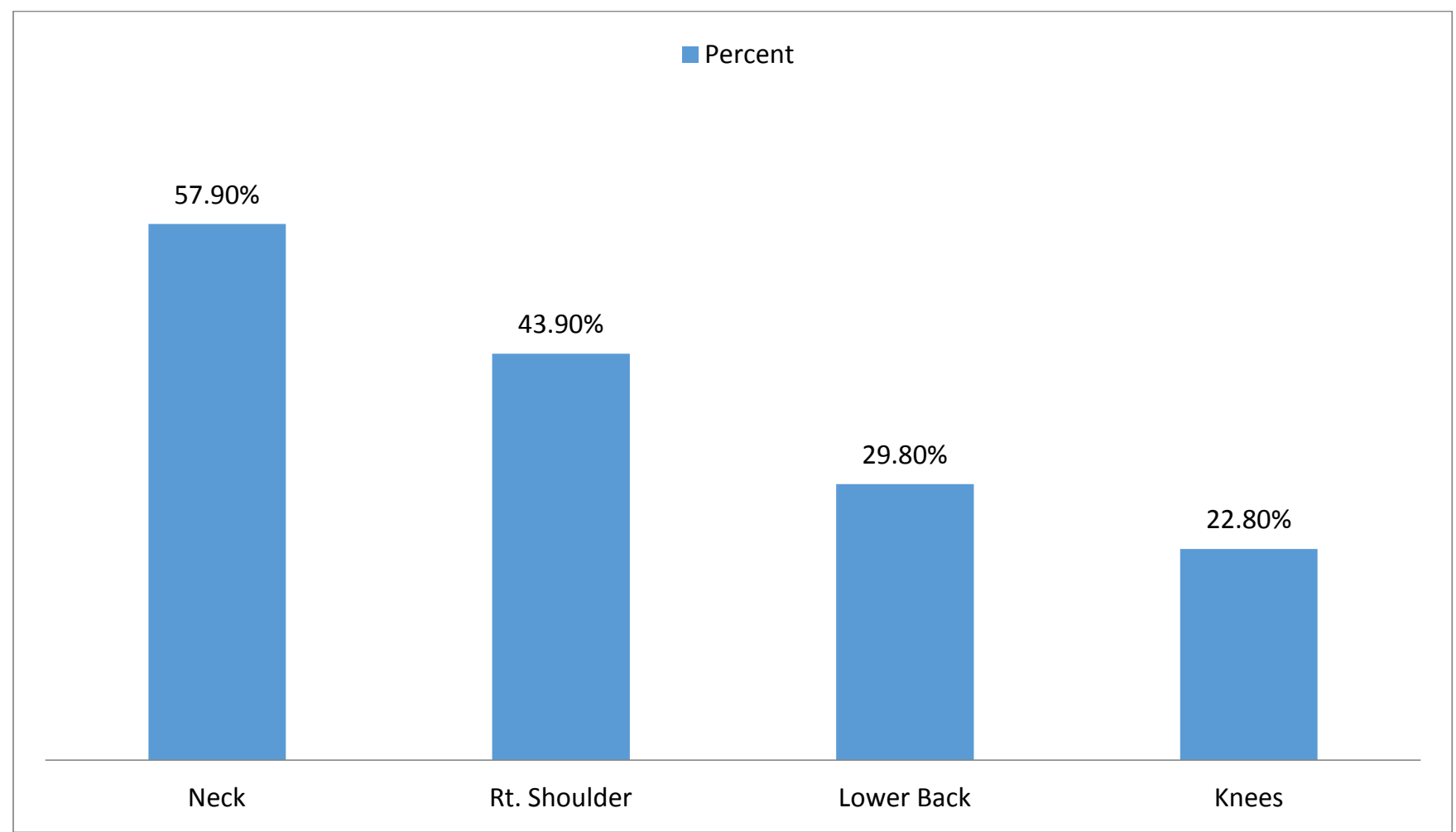

Figure 1. Present of Pain in different body regions from last 12 months $(\mathrm{N}=342)$ 


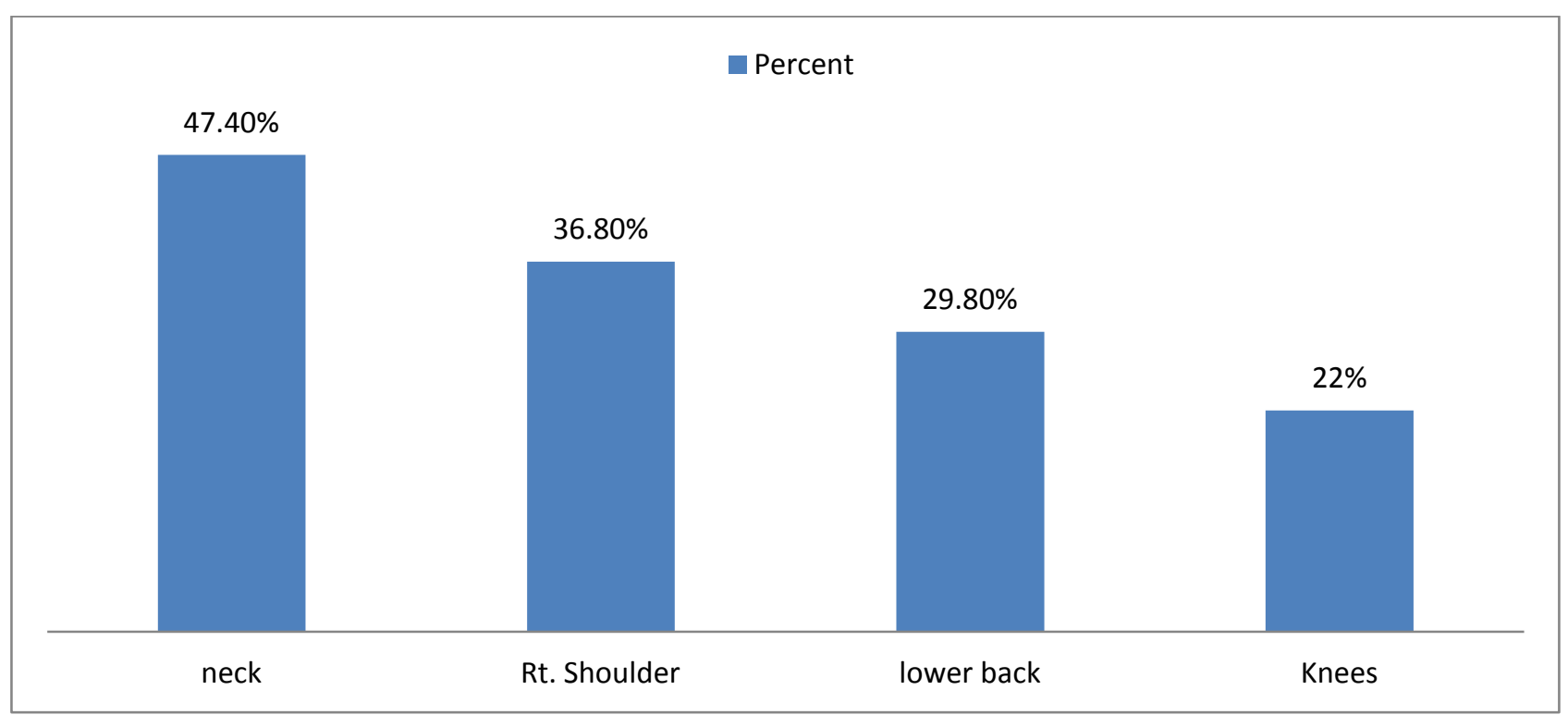

Figure 2. Present of Pain in different body regions from last 7 days $(\mathrm{N}=342)$ 